\title{
Workplace Design Concept Based on Indoor Environmental Quality Analysis to Prevent Coronavirus Transmission
}

\author{
Hilma Tamiami Fachrudin ${ }^{1, *}$, Khaira Amalia Fachrudin², Imam Faisal Pane ${ }^{1}$ \\ ${ }^{1}$ Department of Architecture, Faculty of Engineering, Universitas Sumatera Utara, Medan 20155, Indonesia \\ ${ }^{2}$ Department of Management, Faculty of Economics and Business, Universitas Sumatera Utara, Medan 20155, Indonesia
}

Received October 19, 2021; Revised November 22, 2021; Accepted December 22, 2021

\section{Cite This Paper in the following Citation Styles}

(a): [1] Hilma Tamiami Fachrudin, Khaira Amalia Fachrudin, Imam Faisal Pane , "Workplace Design Concept Based on Indoor Environmental Quality Analysis to Prevent Coronavirus Transmission," Civil Engineering and Architecture, Vol. 10, No. 1, pp. 121 - 130, 2022. DOI: 10.13189/cea.2022.100111.

(b): Hilma Tamiami Fachrudin, Khaira Amalia Fachrudin, Imam Faisal Pane (2022). Workplace Design Concept Based on Indoor Environmental Quality Analysis to Prevent Coronavirus Transmission. Civil Engineering and Architecture, 10(1), 121 - 130. DOI: 10.13189/cea.2022.100111.

Copyright $₫ 2022$ by authors, all rights reserved. Authors agree that this article remains permanently open access under the terms of the Creative Commons Attribution License 4.0 International License

\begin{abstract}
People spend a lot of time in the workplace, where indoor environmental quality in the room provides the quality of health and comfort. Indoor environmental quality must be supported by a good air system to keep the air in the room healthy and clean. People who work in closed spaces have a greater risk of being exposed to the Covid 19 virus. This research will create a workplace design concept based on an analysis of indoor environmental quality from green building councils in several countries to prevent coronavirus transmission. This research uses qualitative methods with data collection through observation and interviews. The samples were divided into two groups, namely workplace with a centralized air conditioning system and a split air conditioning system. Indoor environmental quality consists of ventilation, air quality, thermal comfort, health protection, and passive design. The results of the analysis show that the workplace with a centralized air conditioning system does not utilize ventilation optimally, maintains air quality using a mechanical air filter that is integrated with the HVAC system, centralized thermal comfort, and has implemented health protection. Workplaces with split air conditioning system maximize ventilation and have indoor air quality management. Occupants can control thermal comfort and implement health protection.
\end{abstract}

Keyword Air Quality, Coronavirus, Indoor Environmental Quality, Ventilation

\section{Introduction}

A Green building is a building that implements energy efficiency and conservation, building environment management, water conservation, indoor health and comfort, appropriate site development, and material resources and cycle [1]. Green buildings contribute to the sustainability of cities and are related to the quality of urban life [2]. Several buildings in Indonesia have implemented the green concept to provide comfort for users, preserve the environment and minimize building operational costs [3].

Green building strategies can be achieved if supported by users and building owners to reduce environmental impacts [4]. A sustainable environment can help improve the quality of urban life. To realize green buildings, it must be supported by green behavior. The implementation of green behavior must be supported by residents and managers as policymakers [5].

Air quality, noise, and light pollution can affect space users. Humans spend a lot of time in the workplace, so the quality of life for building occupants is highly dependent on indoor environment Quality/IEQ [6]. Human health is an important aspect of green building [7] and indoor 
health and comfort can provide an indoor environment quality/IEQ [8].

An unfavorable indoor environment will affect the health and well-being of building occupants, which can also affect workability [9]. Poor indoor environmental quality can cause disease [10]. Environmental quality assessment can be performed on users. The assessment was carried out based on experts and public opinion [2].

During the Covid 19 pandemic, people who worked in closed spaces have a greater risk of being exposed to the Covid 19 virus [11]. Poor ventilation in the workplace may increase the transmission of respiratory infections [12]. Rooms that use a centralized air conditioning system and are shared by several spaces, the system must be operated with $100 \%$ outdoor air [11]. In rooms with centralized air conditioning systems, where temperature and humidity are controlled in the range of $20-25^{\circ} \mathrm{C}$ and $40-70 \%$ by central air conditioning during epidemics, it is found to be beneficial for the health and comfort of occupants, also weaken the vitality of the virus and reduce the risk of transmission [13]. The arrangement of office interiors after the pandemic must pay attention to distance, furniture layout, and air conditioning systems [14].

This study will analyze indoor environmental quality in the workplace based on the Green Building Councils from various countries which can be applied in the workplaces design concept to prevent coronavirus transmission.

\section{Material and Methods}

This research uses a qualitative method. Research with qualitative methods is used to explore and understand the problems of a people or society from a social or humanitarian perspective [15]. The stages of the research carried out were conducting interviews, collecting data from participants through observation, inductive data analysis, and interpretation.

The research population is workplaces in an office building in Indonesia. The target population is workplaces in office buildings that have employees who are infected with Coronavirus 19 and use an air conditioner as an air system, which is divided into centralized air conditioning and split air conditioning. In an air-conditioned room, the system can adjust the temperature and humidity and ensure human comfort to create a quality indoor environment [13]. The research sample is 10 workplaces, namely 5 workplaces that use centralized air conditioning and 5 workplaces that use split air conditioners. Interviews were conducted with managers in the workplace.

This study uses descriptive data analysis for the results of observations and interviews. The results of observations from each sample are compared and then concluded inductively. The results of the interviews were analyzed descriptively. A descriptive analysis method is an analytical method in which the data have been obtained, compiled, grouped, analyzed, then interpreted objectively to obtain an overview of the problems encountered and to explain the results of the analysis. Then a workplace design concept will be compiled based on an analysis of the IEQ.

\subsection{Workplace}

Workplace in the office is divided into private space as much as $70-80 \%$ and shared space as much as $20-30 \%$ [14]. The Covid 19 pandemic period has resulted in changes in work patterns and the provision of workplaces, one of which is WFH (working from home). Working in an office during a pandemic must pay attention to human connectivity, maintaining normality, social distancing, infrastructure, collaboration, security, policy frameworks, and emotional well-being [16].

A safe workplace arrangement has an individual distance in the workplace of 2 meters or 6 feet and the furniture layout is back to back each other. The size of the office desk has been reduced from $1.8 \mathrm{~m}$ to $1.4 \mathrm{~m}$. The use of panels between employees is required [14]. Some recommendations for workplace design to obtain a usable IEQ according to ASHRAE (2020) [17] consist of dilute, exhaust, control, and cleaning.

An office with a green concept applies an environmentally friendly interior design and is supported by green behavior [18]. An office located in the main building should be designed and managed in an environmentally friendly manner, especially with a high-performance HVAC system [19]. Energy efficiency and employee environmental comfort can be easily achieved.

Workplace in Office Buildings should maintain air quality by optimizing air circulation and sunlight entering the room, cleaning AC filters, carrying out prevention of transmission such as installing barriers or glass screens for workers who serve customers, Screening, physical distancing, limiting the number of people in the elevator and seating arrangements to be 1 meter apart from the desk/work area [20]. Occupant behavior has a major impact on architectural performance. Occupants in green buildings have higher job satisfaction than those in conventional buildings [8].

\subsection{Indoor Environmental Quality (IEQ)}

Office buildings, which have a good IEQ, can increase worker productivity [6]. There are four main variables on the IEQ principle, namely thermal quality, acoustic quality, visual quality, and indoor air quality [8]. Some of the indicators that are considered include a view to the outside, aesthetic appearance; less interference from heating, ventilation, air conditioning, and noise. IEQ depends on factors such as lighting, noise, thermal quality, and air quality [10]. The application of IEQ can increase employee productivity [21]. The principle of health and 
comfort in the room has several measuring indicators, namely the introduction of outdoor air where the design of the room that shows the potential for the introduction of outside air is at least following ASHRAE Standard 62.1-2007, $\mathrm{CO}_{2}$ monitoring, environmental tobacco smoke control, chemical pollutants, views out, visual comfort, thermal comfort and acoustic comfort [22], [1].

Some of the IEQ indicators in buildings are Bringing fresh air into the room, combining natural light and scenery to ensure the comfort and enjoyment of building users around them, and reducing lighting energy requirements in the process, designing for the ears and eyes, and ensuring people feel comfortable in their surroundings, Creating the right indoor temperature through passive design or building management and monitoring systems [23]. Air quality can be measured through minimum indoor air quality performance; Environmental Tobacco Smoke control; Carbon Dioxide monitoring and Control; Indoor Air Pollutants (reducing adverse impact on occupant health from the result emitting internal air pollutants) and prevention mold. Thermal comfort includes System Control and Air Change effectiveness, Lighting, visual and acoustic comfort, and verification [24].

IEQ can be measured from Thermal control, Ventilation control, Microbial contamination, Water requirements, Indoor and outdoor space, Lighting level (Lux), Lighting control, Inclusive design, Ventilation requirements (Fresh air level, Temperature, Indoor environment: CO monitoring, $\mathrm{CO}_{2}$ and $\mathrm{NOx}$ as well as repair/renovation/redecoration), Acoustic conditions, occupant comfort, and Heating, ventilation, and air conditioning or HVAC system [25]. IEQ measurement indicators according to [26] are ventilation in buildings, reducing the impact of pollution/pollution, Achievement of improving quality of life, Control of indoor lighting systems, Use of natural lighting in buildings (45\%-65\%), Thermal comfort: 50\%-70\% Temperature and relative humidity in an air-conditioned area.

Measurements of the indoor environment consist of Tobacco Smoke Pollution, Fresh Air Ventilation, Daylight, Thermal Comfort, Ergonomic Design, $\mathrm{CO}_{2}$ Monitoring, Indoor Plants, Acoustic Performance Materials, Outdoor Views, Minimizing Contamination of Indoor Pollutants, Low Emission Materials and Indoor Air Quality Management [27]. The US Green Building Council through LEED [28], has IEQ measurements for green buildings, namely Minimum Indoor Air Quality Performance with mechanically ventilated spaces and naturally ventilated spaces; Environmental Tobacco Smoke control; improvement of the Indoor Air Quality Strategy; Low Emitting materials; Construction Indoor Air Quality Management Plan; Indoor Air Quality assessment; Thermal comfort; Interior Lighting; daylight; quality view and acoustic performance. Several measuring indicators for the principle of indoor environmental quality based on
[9] are occupant comfort; prohibition of smoking indoors; Fresh Air supply; $\mathrm{CO}_{2}$ monitoring; indoor air quality test (IAQ/Indoor Air Quality); daylight; outward view; Green cleaning and developing and implementing green cleaning programs. There are several measurements of indoor air quality, namely the provision of fresh air, ventilation efficiency, thermal comfort, daylight, $\mathrm{CO}_{2}$ control, pollutant control, acoustic and sound control, and visual quality [19].

\section{(a) Ventilation}

Ventilation serves to enter air and light from outside and provides views to the outside of the building. Ventilation in the form of windows can help provide natural lighting and bring in fresh air from outside [1], [6], [23], [24], [27], [28]. Ventilation in the form of windows can provide access to views outside the building. Employees who can see outside the building can reduce stress at work [1]. The view to the outside of the building is an indicator of indoor environmental quality [6], [27].

\section{(b) Air Quality}

Air quality in the room is very influential on the health of the user. The introduction of outdoor air according to ASHRAE is necessary to provide healthy indoor air quality [1]. Optimization of the HVAC system is required in the workplace [11] and should be open 2 hours before and after occupancy [29], [17]. Monitoring $\mathrm{CO}_{2}$ and $\mathrm{CO}$ levels in the workplace can be done by placing a $\mathrm{CO}_{2}$ sensor at the turning point of each workplace floor to prevent $\mathrm{CO}_{2}$ from being above $1000 \mathrm{ppm}$ [24], [19], [1].

Efforts to control smoke or tobacco in the workplace can be done by providing no smoking signage in the room and providing a special smoking room outside the office building. Indoor smoke control can prevent or minimize exposure of building occupants, indoor surfaces, and air distribution ventilation systems to environmental tobacco smoke [27], [1], [6]. Pollutant control and the use of VOC-free materials aim to reduce the concentration of chemical contaminants that can damage air quality, human health, productivity, and the environment [28] minimize exposure to building occupants from hazardous materials [27], and prevent adverse effects on occupant health [1]. Indoor plants can improve indoor air quality, thereby improving the health and well-being of occupants [27].

\section{(c) Thermal comfort}

Thermal comfort is one indicator of IEQ [19]. Thermal comfort is measured by temperature and relative humidity in air-conditioned rooms [1], [27], indoor air quality management [27], HVAC system operations [30] and, air filters [29].

\section{(d) Health Protection}

Health Protection must be implemented to prevent the spread of the Covid 19 virus in the workplace. Some of the 
efforts that can be made are the existence of air exchange in the room [17], Restrictions on space users [12], Layout of work desks by providing a minimum distance between work desks of 1.5 meters [29], [20], regulation of the number of people in the room [17], [12], regulation of working days and hours [17]. Efforts to implement the Health protocol in the workplace include wearing masks, disinfecting the room, and providing a place to wash hands [12], [20].

\section{(e) Passive Design}

The workplace can be designed using a building envelope with a glass cover so that daylight can enter the room [1], [28]. The use of this building envelope affects the comfort of the indoor space [28]. In a workplace with a centralized air conditioning system, it is necessary to optimize the performance of the air conditioning system [1].

\section{Results and Discussion}

Analysis of the IEQ application in workplaces is divided into two groups, namely workplace that use centralized air conditioning systems and split air conditioning systems. The results of the analysis can be seen in table 1 .

Table 1. Implementation of IEQ in workplaces

\begin{tabular}{|c|c|c|c|c|c|c|c|c|c|c|}
\hline \multirow{3}{*}{$\begin{array}{l}\text { Variables and } \\
\text { Indicators }\end{array}$} & \multicolumn{10}{|c|}{ Workplaces } \\
\hline & \multicolumn{5}{|c|}{ centralized air conditioning system } & \multicolumn{5}{|c|}{ split air conditioning system } \\
\hline & wp1 & wp2 & wp3 & wp4 & wp5 & wp1 & wp2 & wp3 & wp4 & wp5 \\
\hline \multicolumn{11}{|c|}{ Ventilation } \\
\hline $\begin{array}{l}\text { Natural } \\
\text { lighting }\end{array}$ & $\mathrm{x}$ & $\mathrm{x}$ & $\mathrm{x}$ & $\mathrm{x}$ & $\mathrm{x}$ & $\mathrm{v}$ & $\mathrm{v}$ & $\mathrm{v}$ & $\mathrm{v}$ & $\mathrm{v}$ \\
\hline Daylight & $\mathrm{x}$ & $\mathrm{x}$ & $\mathrm{x}$ & $\mathrm{x}$ & $\mathrm{x}$ & $\mathrm{v}$ & $\mathrm{v}$ & $\mathrm{v}$ & $\mathrm{v}$ & $\mathrm{v}$ \\
\hline $\begin{array}{l}\text { View to } \\
\text { outside }\end{array}$ & $\mathrm{v}$ & $\mathrm{v}$ & $\mathrm{v}$ & $x$ & $x$ & $\mathrm{v}$ & $\mathrm{v}$ & $\mathrm{v}$ & $\mathrm{v}$ & $\mathrm{v}$ \\
\hline Fresh air & $\mathrm{x}$ & $\mathrm{x}$ & $\mathrm{x}$ & $\mathrm{x}$ & $\mathrm{x}$ & $\mathrm{v}$ & $\mathrm{v}$ & $\mathrm{v}$ & $\mathrm{v}$ & $\mathrm{v}$ \\
\hline $\begin{array}{c}\text { Air cleaning } \\
\text { (opens } \\
\text { windows every } \\
4 \text { hours) } \\
\end{array}$ & $\mathrm{x}$ & $\mathrm{x}$ & $\mathrm{x}$ & $\mathrm{x}$ & $\mathrm{x}$ & $\mathrm{v}$ & $\mathrm{v}$ & $\mathrm{v}$ & $\mathrm{v}$ & $\mathrm{v}$ \\
\hline \multicolumn{11}{|c|}{ Air Quality } \\
\hline $\begin{array}{c}\text { Outdoor air } \\
\text { introduction } \\
\text { based on } \\
\text { ASHRAE } \\
\end{array}$ & $\mathrm{x}$ & $\mathrm{x}$ & $\mathrm{x}$ & $\mathrm{x}$ & $\mathrm{x}$ & $\mathrm{x}$ & $\mathrm{x}$ & $\mathrm{x}$ & $\mathrm{x}$ & $\mathrm{x}$ \\
\hline $\begin{array}{l}\text { Optimization } \\
\text { HVAC system }\end{array}$ & $\mathrm{V}$ & $\mathrm{V}$ & $\mathrm{V}$ & $\mathrm{v}$ & $\mathrm{v}$ & $\mathrm{x}$ & $\mathrm{x}$ & $x$ & $\mathrm{x}$ & $\mathrm{x}$ \\
\hline $\begin{array}{c}\mathrm{CO}_{2} \text { and } \mathrm{CO} \\
\text { Monitoring }\end{array}$ & $\mathrm{x}$ & $x$ & $x$ & $x$ & $x$ & $\mathrm{x}$ & $x$ & $\mathrm{x}$ & $\mathrm{x}$ & $\mathrm{x}$ \\
\hline $\begin{array}{c}\begin{array}{l}\text { Tobacco } \\
\text { control }\end{array} \\
\end{array}$ & $\mathrm{v}$ & $\mathrm{v}$ & $\mathrm{v}$ & $\mathrm{v}$ & $\mathrm{x}$ & $\mathrm{x}$ & $\mathrm{x}$ & $\mathrm{x}$ & $\mathrm{x}$ & $\mathrm{x}$ \\
\hline $\begin{array}{c}\text { Control of } \\
\text { pollutants and } \\
\text { VOC-free } \\
\text { materials }\end{array}$ & $\mathrm{v}$ & $\mathrm{v}$ & $\mathrm{v}$ & $\mathrm{v}$ & $\mathrm{x}$ & $\mathrm{x}$ & $\mathrm{x}$ & $\mathrm{x}$ & $\mathrm{x}$ & $\mathrm{x}$ \\
\hline $\begin{array}{c}\text { Air cleaning } \\
\text { efficiency }\end{array}$ & $\mathrm{v}$ & $\mathrm{v}$ & $\mathrm{v}$ & $\mathrm{v}$ & $\mathrm{v}$ & $\mathrm{v}$ & $\mathrm{v}$ & $\mathrm{v}$ & $\mathrm{v}$ & $\mathrm{v}$ \\
\hline Air Filter & $\mathrm{v}$ & $\mathrm{v}$ & $\mathrm{v}$ & $\mathrm{v}$ & $\mathrm{x}$ & $\mathrm{x}$ & $\mathrm{x}$ & $\mathrm{x}$ & $\mathrm{v}$ & $\mathrm{x}$ \\
\hline Indoor plants & $\mathrm{v}$ & $\mathrm{v}$ & $\mathrm{v}$ & $\mathrm{v}$ & $\mathrm{x}$ & $\mathrm{v}$ & $\mathrm{v}$ & $\mathrm{v}$ & $\mathrm{x}$ & $\mathrm{x}$ \\
\hline
\end{tabular}




\begin{tabular}{|c|c|c|c|c|c|c|c|c|c|c|}
\hline \multicolumn{11}{|c|}{ Thermal Comfort } \\
\hline $\begin{array}{l}\text { Temperature } \\
\text { and relative } \\
\text { humidity in an } \\
\text { air-conditioned } \\
\text { room }\end{array}$ & $\begin{array}{l}\text { Can't be } \\
\text { set }\end{array}$ & $\begin{array}{c}\text { Can't be } \\
\text { set }\end{array}$ & $\begin{array}{l}\text { Can't be } \\
\text { set }\end{array}$ & $\begin{array}{c}\text { Can't be } \\
\text { set }\end{array}$ & $\begin{array}{c}\text { Can't be } \\
\text { set }\end{array}$ & $\begin{array}{l}\text { Can be } \\
\text { set }\end{array}$ & $\begin{array}{l}\text { Can be } \\
\text { set }\end{array}$ & $\begin{array}{l}\text { Can be } \\
\text { set }\end{array}$ & $\begin{array}{l}\text { Can be } \\
\text { set }\end{array}$ & $\begin{array}{l}\text { Can be } \\
\text { set }\end{array}$ \\
\hline $\begin{array}{c}\text { Thermal } \\
\text { modeling for } \\
\text { temperature } \\
\text { control }\end{array}$ & $\mathrm{x}$ & $\mathrm{x}$ & $\mathrm{x}$ & $\mathrm{x}$ & $\mathrm{x}$ & $\mathrm{x}$ & $\mathrm{x}$ & $\mathrm{x}$ & $\mathrm{x}$ & $\mathrm{x}$ \\
\hline $\begin{array}{c}\text { Indoor air } \\
\text { quality } \\
\text { management }\end{array}$ & $\mathrm{x}$ & $\mathrm{x}$ & $\mathrm{x}$ & $\mathrm{x}$ & $\mathrm{x}$ & $\mathrm{v}$ & $\mathrm{v}$ & $\mathrm{v}$ & $\mathrm{x}$ & $\mathrm{v}$ \\
\hline $\begin{array}{c}\text { HVAC system } \\
\text { operation }\end{array}$ & $\mathrm{v}$ & $\mathrm{v}$ & $\mathrm{v}$ & $\mathrm{v}$ & $\mathrm{v}$ & $\mathrm{x}$ & $\mathrm{x}$ & $\mathrm{x}$ & $\mathrm{x}$ & $\mathrm{x}$ \\
\hline Air filter & $\mathrm{v}$ & $\mathrm{v}$ & $\mathrm{v}$ & $\mathrm{v}$ & $\mathrm{v}$ & $\mathrm{x}$ & $\mathrm{x}$ & $\mathrm{x}$ & $\mathrm{v}$ & $\mathrm{x}$ \\
\hline \multicolumn{11}{|c|}{ Health protection } \\
\hline $\begin{array}{l}\text { Indoor air } \\
\text { exchange }\end{array}$ & $\mathrm{v}$ & $\mathrm{v}$ & $\mathrm{v}$ & $\mathrm{v}$ & $\mathrm{v}$ & $\mathrm{v}$ & $\mathrm{v}$ & $\mathrm{v}$ & $\mathrm{v}$ & $\mathrm{v}$ \\
\hline $\begin{array}{l}\text { Space user } \\
\text { restriction }\end{array}$ & $\mathrm{v}$ & $\mathrm{v}$ & $\mathrm{v}$ & $\mathrm{v}$ & $\mathrm{v}$ & $\mathrm{v}$ & $\mathrm{v}$ & $\mathrm{v}$ & $\mathrm{v}$ & $\mathrm{v}$ \\
\hline $\begin{array}{c}\text { Furniture } \\
\text { layout }\end{array}$ & Cubical & Cubical & Cubical & Cubical & Cubical & linear & linear & linear & linear & linear \\
\hline $\begin{array}{l}\text { Furniture } \\
\text { distance }\end{array}$ & $\begin{array}{c}1,2 \mathrm{~m} \\
\text { with } \\
\text { barrier }\end{array}$ & $\begin{array}{c}1,2 \mathrm{~m} \\
\text { with } \\
\text { barrier }\end{array}$ & $\begin{array}{c}1,2 \mathrm{~m} \\
\text { with } \\
\text { barrier }\end{array}$ & $\begin{array}{c}1,2 \mathrm{~m} \\
\text { with } \\
\text { barrier }\end{array}$ & $\begin{array}{c}1 \text { m with } \\
\text { barrier }\end{array}$ & $\begin{array}{c}1 \mathrm{~m} \\
\text { without } \\
\text { barrier }\end{array}$ & $\begin{array}{c}1 \mathrm{~m} \\
\text { without } \\
\text { barrier }\end{array}$ & $\begin{array}{c}1 \mathrm{~m} \\
\text { without } \\
\text { barrier }\end{array}$ & $\begin{array}{l}1-1,2 \mathrm{~m} \\
\text { without } \\
\text { barrier }\end{array}$ & $\begin{array}{l}1-1,2 \mathrm{~m} \\
\text { without } \\
\text { barrier }\end{array}$ \\
\hline $\begin{array}{l}\text { Setting the } \\
\text { number of } \\
\text { people in the } \\
\text { room }\end{array}$ & $\mathrm{v}$ & $\mathrm{v}$ & $\mathrm{v}$ & $\mathrm{v}$ & $\mathrm{v}$ & $\mathrm{v}$ & $\mathrm{v}$ & $\mathrm{v}$ & $\mathrm{v}$ & $\mathrm{v}$ \\
\hline $\begin{array}{c}\text { Setting } \\
\text { working days } \\
\text { and hours } \\
\end{array}$ & $\mathrm{v}$ & $\mathrm{v}$ & $\mathrm{v}$ & $\mathrm{v}$ & $\mathrm{x}$ & $\mathrm{x}$ & $\mathrm{x}$ & $\mathrm{x}$ & $\mathrm{x}$ & $\mathrm{x}$ \\
\hline Thermogun & $\mathrm{v}$ & $\mathrm{v}$ & $\mathrm{v}$ & $\mathrm{v}$ & $\mathrm{v}$ & $\mathrm{v}$ & $\mathrm{v}$ & $\mathrm{v}$ & $\mathrm{v}$ & $\mathrm{v}$ \\
\hline $\begin{array}{c}\text { Hand-washing } \\
\text { place }\end{array}$ & $\mathrm{v}$ & $\mathrm{v}$ & $\mathrm{v}$ & $\mathrm{v}$ & $\mathrm{v}$ & $\mathrm{v}$ & $\mathrm{v}$ & $\mathrm{v}$ & $\mathrm{v}$ & $\mathrm{v}$ \\
\hline Handsanitizer & $\mathrm{v}$ & $\mathrm{v}$ & $\mathrm{v}$ & $\mathrm{v}$ & $\mathrm{v}$ & $\mathrm{v}$ & $\mathrm{v}$ & $\mathrm{v}$ & $\mathrm{v}$ & $\mathrm{v}$ \\
\hline $\begin{array}{c}\text { Wearing a } \\
\text { mask }\end{array}$ & $\mathrm{v}$ & $\mathrm{v}$ & $\mathrm{v}$ & $\mathrm{v}$ & $\mathrm{v}$ & $\mathrm{v}$ & $\mathrm{v}$ & $\mathrm{v}$ & $\mathrm{v}$ & $\mathrm{v}$ \\
\hline Disinfectan & $\mathrm{v}$ & $\mathrm{v}$ & $\mathrm{v}$ & $\mathrm{v}$ & $\mathrm{v}$ & $\mathrm{v}$ & $\mathrm{v}$ & $\mathrm{v}$ & $\mathrm{v}$ & $\mathrm{v}$ \\
\hline \multicolumn{11}{|c|}{ People Infected Coronavirus 19} \\
\hline $\begin{array}{c}\text { Number of } \\
\text { residents } \\
\text { infected with } \\
\text { coronavirus } \\
\end{array}$ & 10 & 8 & 9 & 8 & 5 & 3 & 2 & 1 & 3 & 3 \\
\hline
\end{tabular}

Source: Observation and interview on July-August 2021 (author)

Note:

$\mathrm{Wp}=$ workplace

$\mathrm{V}=$ yes

$\mathrm{X}=$ no

\subsection{Ventilation}

Workplaces with centralized air conditioning systems rely on artificial lighting. The glass window in the room was not opened. Air cleaning is not done manually but depends on an exhaust fan (Figure 1). While the workplace with a split air conditioning system utilizes natural lighting to enter the workplace by opening the window, namely in the morning, afternoon and, evening. In addition, windows are used to introduce fresh air into the room as well as to clean the air (figure 2).

These workplaces have a view to the outside of the 
building because they use glass windows in the building envelope. Efforts to utilize natural light, include fresh air and clean the air according to research by [1], [11].

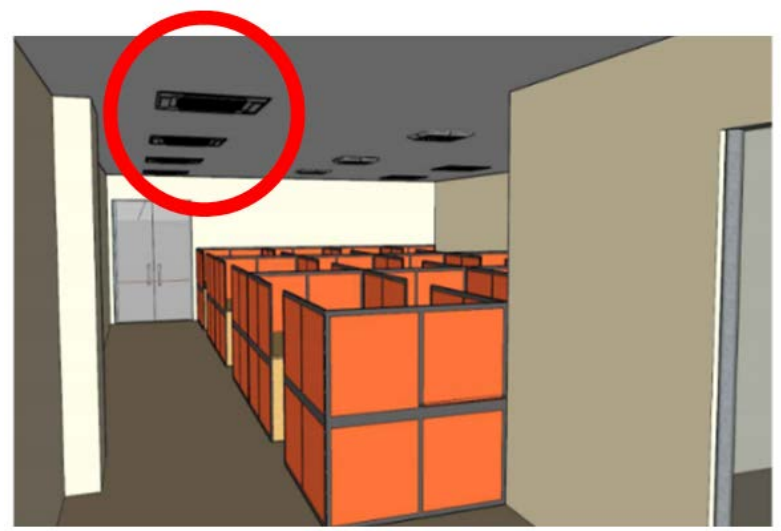

Source: Observation on July-August 2021 (author)

Figure 1. Exhaust fan

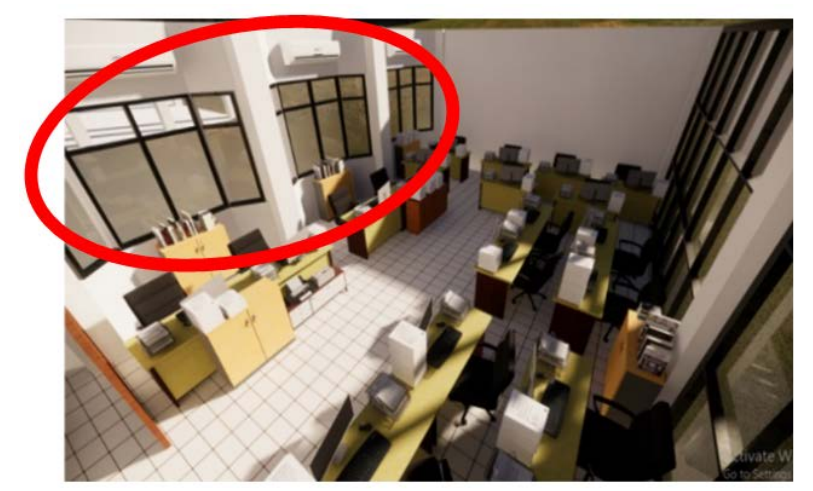

Source: Observation on July-August 2021 (author)

Figure 2. Ventilation

\subsection{Air Quality}

Air quality in the workplace can help occupants become healthier. However, not all workplaces have optimized the air system, monitored $\mathrm{CO}_{2}$ levels, and used pollutant-free materials. Workplaces with a centralized air conditioning system controlled tobacco smoke used air filters, and introduced plants into the room (Figure 3). These rooms perform mechanical air cleaning efficiency and open the door of the room.
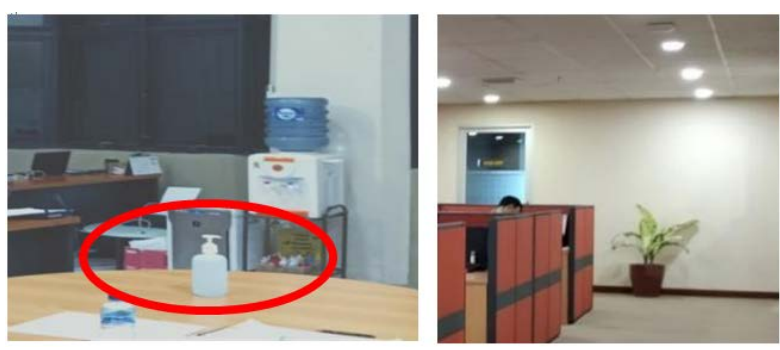

Source: Observation on July-August 2021 (author)

Figure 3. Air Purifying and vegetation
Workplaces with a split air conditioning system perform the efficiency of manual air cleaning by opening windows and doors. Air cleaning is done by putting air purifying and plants in the room. This is done to prevent the transmission of coronavirus in space. The provision of air quality in the workplace is in accordance with [24], [27].

\subsection{Thermal Comfort}

The temperature and relative humidity in the workplaces of the centralized air conditioning system cannot be controlled by the occupants because the settings are centralized, using an HVAC system and air filters. However, these spaces do not have indoor air quality management. While in the workplaces with a split air conditioning system, the temperature can be controlled by the occupants and some have an air filter. Thermal comfort in the room should follow the standards of [29], [30]. Thermal comfort is needed to provide comfort and health in the room.

\subsection{Health Protection}

To provide an IEQ and prevent the spread of coronavirus in the workplace, health protection efforts must be made. During the pandemic and after, health protection must be carried out both in workplaces with centralized air conditioning systems and split air conditioning systems. Air exchange in the room is done by opening windows and doors before and after occupancy. Occupants' restrictions are carried out with a work-from-home policy. In a workplace with a centralized air conditioning system, the table is arranged cubically and has a divider on the table. While the workplace is equipped with a centralized air conditioning system, the table is arranged linearly with a minimum distance of $1 \mathrm{~m}$.

Before entering the workplace, residents are required to wash their hands, check their temperature, wear masks and use hand sanitizer. The workplace is sprayed with disinfectant after occupancy. The health protection efforts carried out are in accordance with [12], [17], [20], [29].

\subsection{People Infected Coronavirus 19}

In workplaces with a centralized air conditioning system, as many as 5-10 people have been infected with coronavirus 19. The infected occupants are those who are close to the air source from the air conditioner. They work in the same room and are infecting each other. This is because the air system is centralized and opens the door only at certain times.

While in the split air conditioning system, the number of occupants affected by the virus is 1-3 people. Infected occupants are in direct contact with the air conditioner. In these workplaces, windows and doors are opened periodically, once every 4 hours, especially during the COVID-19 pandemic. This is intended to exchange the air 
in the room. The number of people infected with coronavirus was more found in the workplace with a centralized air conditioning system. This is contrary to the research of [13].

\subsection{Passive Design for Workplace}

IEQ is an important part of the workplace. The workplace design concept based on the IEQ analysis is to maximize ventilation, maintain air quality, provide thermal comfort and follow established health protection (Figure 4 and 5). All of these indicators are applied to the design, namely using building envelopes that can maximize light and air entering the workplace, regulating temperature and relative humidity, optimizing the air conditioning system, and following health protection to prevent the spread of coronavirus in the workplace. Table spacing and the use of dividers or cubicles in the space can minimize direct contact between occupants (Figure 6).

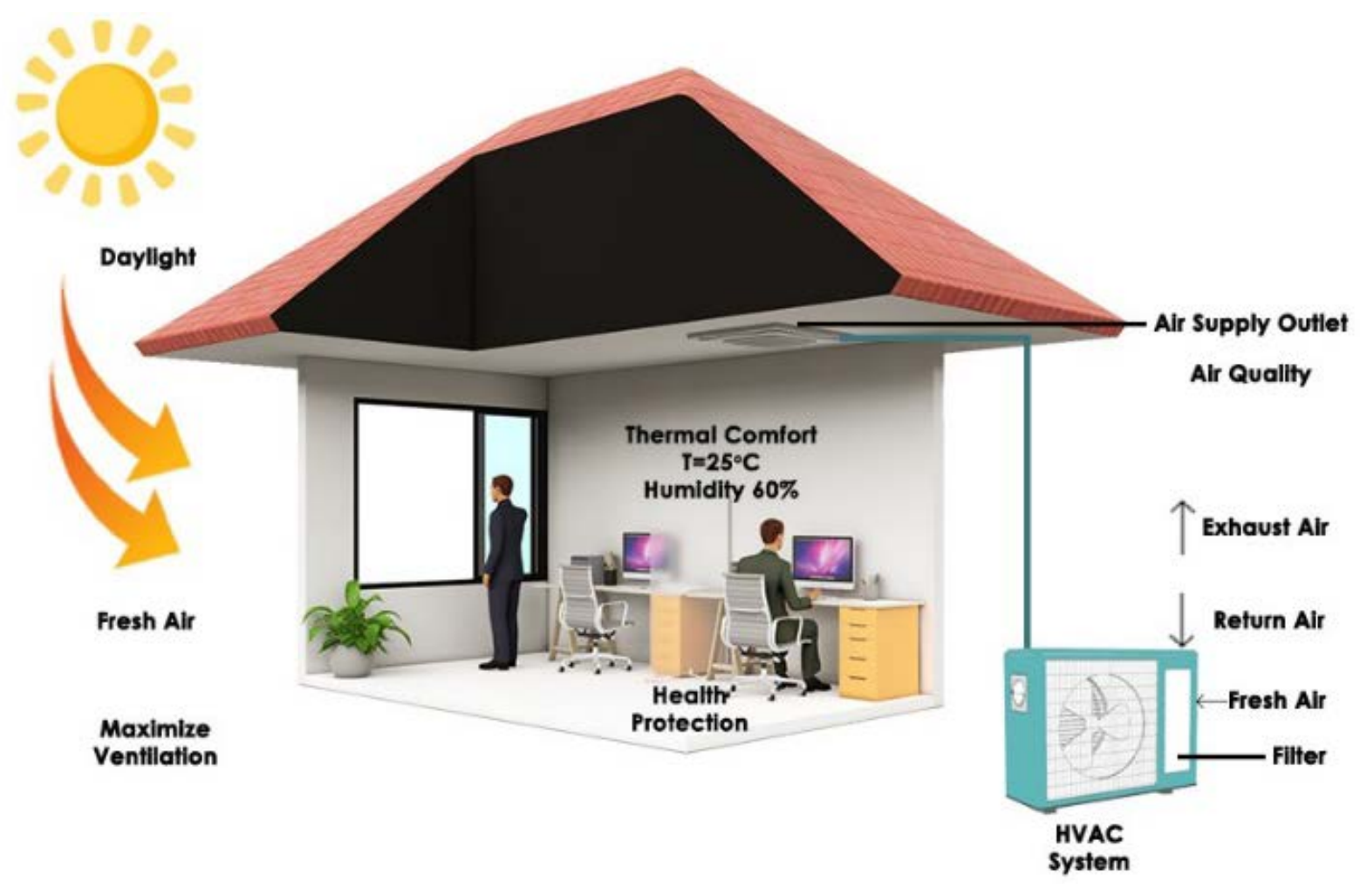

Source: author (2021)

Figure 4. Workplace Design Concept based on IEQ for Centralized AC System 


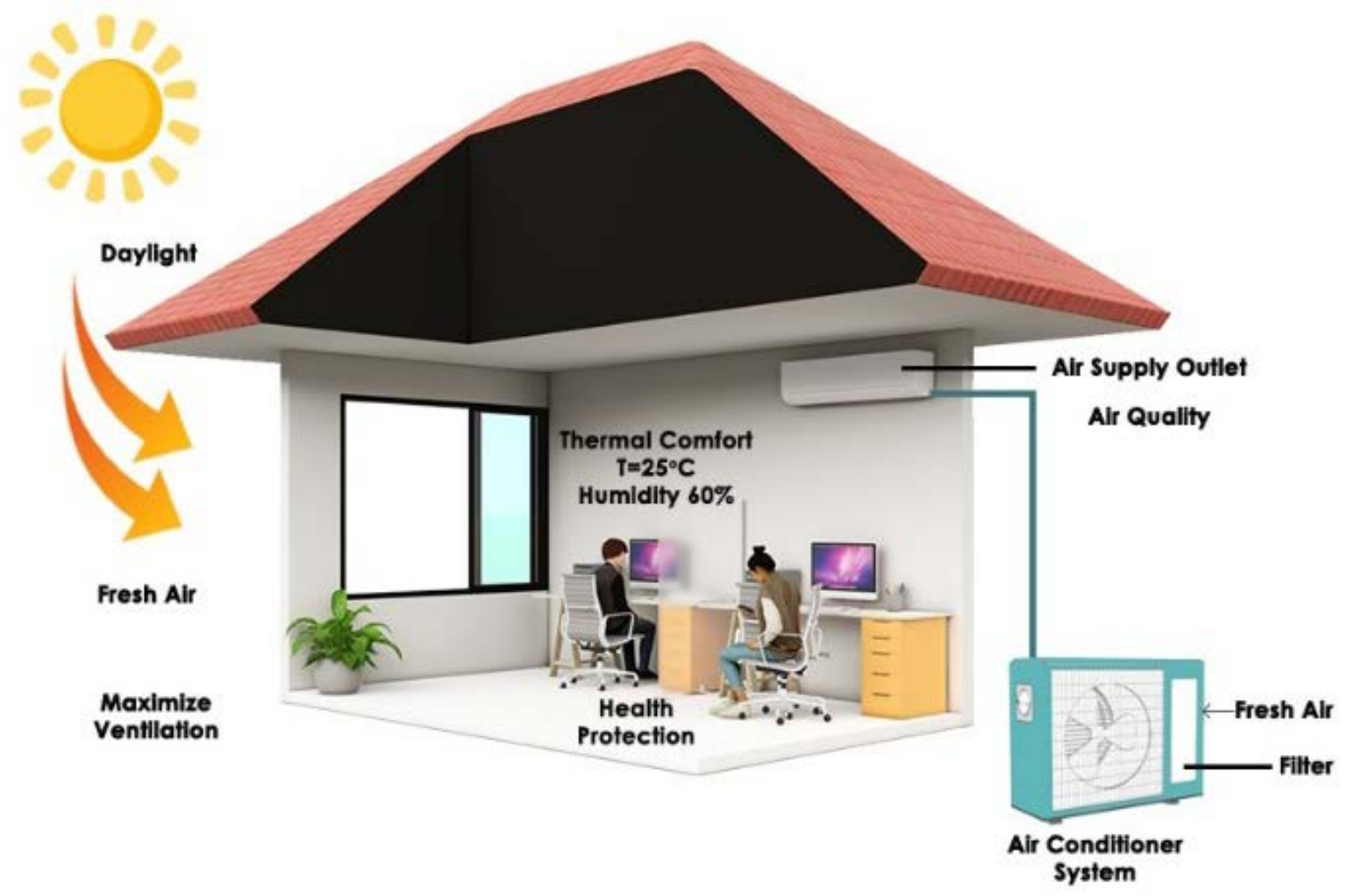

Source: author (2021)

Figure 5. Workplace Design Concept based on IEQ for Split AC System
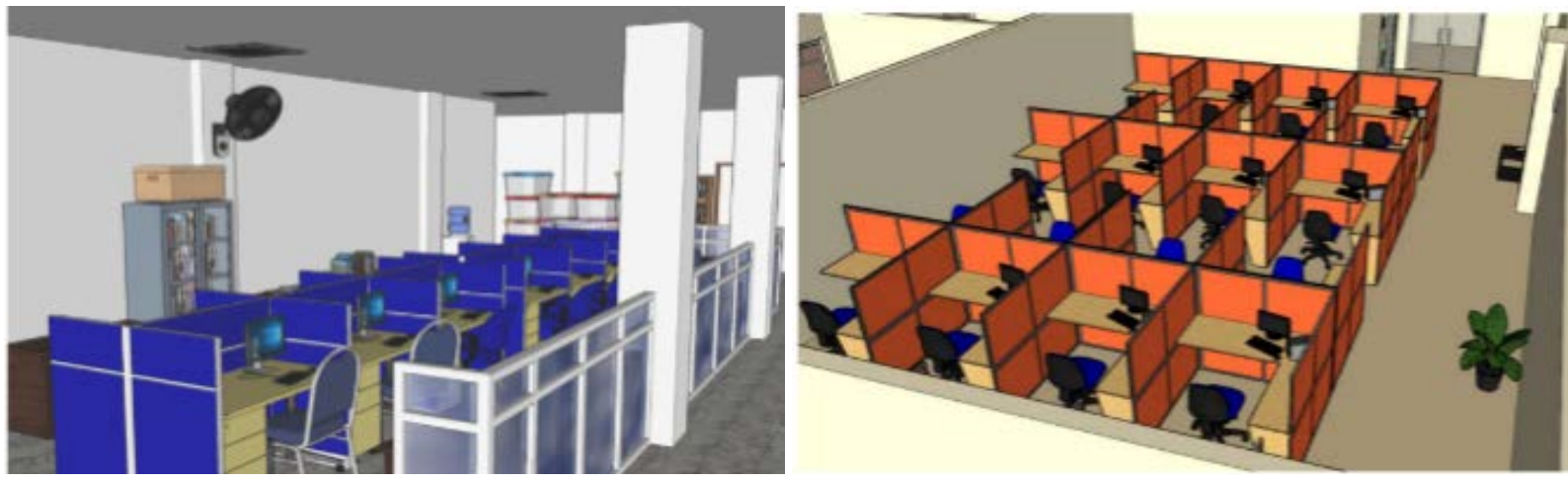

Source: author (2021)

Figure 6. Workplace Layout

\section{Conclusions}

Workplaces with centralized air conditioning systems do not take full advantage of ventilation as natural lighting and make little effort to bring in fresh air from outside. This room relies on a mechanical air filter integrated with the HVAC system to maintain air quality. The room temperature cannot be controlled by the occupants so that thermal comfort is maintained. Air in a closed workplace plays a very important role in the spread of the virus [11], [12].

Workplaces with split air conditioning systems make maximum use of ventilation for natural lighting, enter fresh air from outside, and have indoor air quality management. Thermal comfort through the room temperature can be set by the occupants. Indoor air exchange is very helpful in preventing the spread of the virus.

All workplaces have carried out comprehensive health protection from the occupants entering the room to finishing using the room. Utilizing ventilation, maintaining air quality, maintaining thermal comfort, and health protection is indispensable in providing a healthy IEQ, especially in workplaces in office buildings. 


\section{Acknowledgments}

This research is funded by Research Institution, Universitas Sumatera Utara, according to the research funding agreement letter of TALENTA Universitas Sumatera Utara in the 2021 budget Year Number: 6789/UN5.1.R /PPM /2021, 16 June 2021.

\section{REFERENCES}

[1] GBCI, “Greenship: Technical Manual Green Building Rating Tool For New Building Version 1.2”, Divisi Rating Dan Teknologi Green Building Council Indonesia, Second Edition, GBCI: Jakarta, Indonesia, 2018.

[2] Bonaiuto, M., Fornara F., "Residential Satisfaction and Perceived Urban Quality”, In Reference Module in Neuroscience and Biobehavioral Psychology, Stein, J., Ed. Elsevier: Oxford, UK, 2017, pp. 1-5, http://dx.doi.org/10.1016/B978-0-12-809324-5.05698-4.

[3] Fachrudin K. A., Fachrudin. H. T., "The Effect of Green Home, Green Behavior, and Livability on the Financial Incentive in Medan City, Indonesia”, IOP Conf. Ser.: Mater. Sci. Eng., 180 012002, 2017, DOI: 10.1088/1757-899X/180/1/012002.

[4] Armstrong, B., “Green building strategies”, Manitoba Business, Vol 3, No. 2, pp. 14, 2008.

[5] Fachrudin H. T., Fachrudin K. A., "Factors Influencing Energy Conservation Application in Green Campus Design Based on Green Behavior”, International Journal of Energy Economics and Policy, Vol. 11, No. 4, pp. 511-520, 2021, DOI: https://doi.org/10.32479/ijeep.11355.

[6] VGBC, "LOTUS Buildings in Operation V1, Technical Manual, LOTUS BIO V1 Updated Version”, Vietnam Green Building Council, 2019, https://vgbc.vn/en/lotus-bio/, accessed 16 April 2021.

[7] Brown, K.A., “Incorporating Green-Building Design Principles into Campus Facilities Planning: Obstacles and Opportunities”, Thesis the Faculty of the College of Arts and Science of OHIO University, 2006.

[8] Zhang Y., Wang H., Gao W., Wang F., Zhou N, Kammen D., Ying X., "A Survey of the Status and Challenges of Green Building Development in Various Countries", Sustainability, Vo. 11, No. 5385, pp. 1-29, 2019, DOI: 10.3390/su11195385/1/012002

[9] TGBI TREES, “Thai's Rating of Energy and Environmental Sustainability for Existing Building: Operation and Maintenance”, Thailand Green Building Insitute, 2021, https://tgbi.or.th/uploads/trees/2017_03_TR EES-EB-Eng.pdf, accessed 16 April 2021.

[10] Esfandiari M., Zaid S.M., Ismail M.A., Aflaki A., "Influence of indoor environmental quality on work productivity in green office buildings: a review", Chemical Engineering Transactions, Vol. 56, pp. 385-390, 2017, DOI: 10.3303/CET1756065.

[11] Guo M., Xu P., Xiao T., He R., Dai M., Miller S. L.,
"Review and comparison of HVAC operation guidelines in different countries during the COVID-19 pandemic", Building and Environment, Vol. 187, No. 107368, 2021, https://doi.org/10.1016/j.buildenv.2020.107368.

[12] ECDC, "Heating, ventilation and air-conditioning systems in the context of COVID-19: first update”, European Centre for Disease Prevention and Control, Stockholm: ECDC, 2020, https://www.ecdc.europa.eu/sites/default/files/docu ments/Heating-ventilation-air-conditioning-systems-in-thecontext-of-COVID-19-first-update.pdf, accessed 8 March 2021.

[13] Jia Y., Xiang Y., Guo S., Guo L., Guo L., Cheng Z., Zhang Y., Zhang L., Long E., "Analysis on the risk of respiratory virus transmission by air conditioning system operation based on experimental evidence”, Environmental Science and Pollution Research, Vol. 28, pp. 56376-56391, 2021, https://doi.org/10.1007/s11356-021-14495-0.

[14] Nediari A., Roesli C., Simanjuntak P. M., "Preparing post Covid-19 pandemic office design as the new concept of sustainability design”, IOP Conf. Ser.: Earth Environ. Sci., 729 01209, 2021, DOI: 10.1088/1755-1315/729/1/012095.

[15] J. W. Creswell, Research Design-Pendekatan Metode Kualitatif, kuantitatif dan Campuran, $4^{\text {th }}$ ed. Yogyakarta: Pustaka Pelajar, 2017.

[16] Kaushik M., Guleria N., "The Impact of Pandemic COVID -19 in Workplace”, European Journal of Business and Management, Vol. 12, No. 15, 2020, DOI: 10.7176/EJBM/12-15-02.

[17] ASHRAE, "Updated ASHRAE® Recommendations for COVID-19”, providing insights for today's hvac system designer, Engineers Newsletter, vol. 49-2, 2020, https://www.tranehk.com/files/News/EngrNewsletter/Tran e\%20Engineers\%20Newsletter_vol49_2.pdf, accessed 18 March 2021.

[18] Holtkamp T., S., "Sustainability in the field of new work an empirical study \& potential analysis of green coworking spaces”, in Annette Kämpf-Dern and Mascha Will-Zocholl (eds.), "FUTURE WORKPLACES", Proceedings of the Transdisciplinary Workplace Research (TWR), Conference 2020 Future Workplaces, Frankfurt: German, September, 2020, pp. 26-42.

[19] Gou Z., "Green building for office interiors: challenges and opportunities”, Facilities, Vol. 34, No. 11/12, pp. 614-629, 2016, DOI: 10.1108/F-04-2015-0022.

[20] Kemenkes RI., “Keputusan Menteri Kesehatan Republik Indonesia Nomor Hk.01.07/Menkes/328/2020, Panduan Tentang Pencegahan Dan Pengendalian Corona Virus Disease 2019 (Covid-19) Di Tempat Kerja Perkantoran Dan Industri Dalam Mendukung Keberlangsungan Usaha Pada Situasi Pandemi”, 2020, http://hukor.kemkes.go.id/uploads /produk_hukum/KMK_No_HK_01_07-MENKES-328-2 020_ttg_Panduan_Pencegahan_Pengendalian_COVID-19_ di_Perkantoran_dan_Industri.pdf, accessed 8 March 2021.

[21] Ragheb A., El-Shimy H., Ragheb G., "Green Architecture: A Concept of Sustainability”, Procedia - Social and Behavioral Sciences, Vol. 216, pp. 778 - 787, 2016.

[22] GBCI, "Greenship Existing Building Version 1.1, Divisi Rating Dan Teknologi Green Building Council Indonesia, www.gbcindonesia.org, 2016, accessed 28 February 2021. 
[23] WGBC, “About Green building”, World Green Building Council, https://www.worldgbc.org/how-can-we-make-our -buildings-green, accessed 8 April 2021.

[24] GBI Index, “Green Building Index Assessment Criteria For Nreb, First Edition, Version 1.1”, GREEN BUILDING INDEX SDN BHD (845666-V), January 2011,https://www.greenbuildingindex.org/Files/Resources/ GBI\%20Tools/GBI\%20NREB\%20Non-Residential\%20Ex isting\%20Building\%20Tool\%20V1.1\%20Final.pdf, accessed 12 April 2021.

[25] BREEAM, "BREEAM In-Use International Scheme Update Summary of Changes 2015 to V6”, BRE Global Ltd., https://files.bregroup.com/breeam/BREEAM-In-UseInternational_Update-Summary-2015-to-V6.pdf, accessed 25 July 2021.

[26] TGBI TREES, “Thai's Rating of Energy and Environmental Sustainabilityfor Existing Building: Operation and Maintenance", Thai Gren Building Insitute,https://tgbi.or.th/uploads/trees/2017_03_TREES-E B-Eng.pdf, accessed 16 April 2021.

[27] IGBC, “Green Interiors Rating System Version 1.0, For
New \& Existing Interior Fit-outs”, Abridged Version Release: 2015 Updated with Addendum: 2019, Indian Green building System, India, 2019, https://igbc.in/igbc/html_pdfs/abridged/IGBC\%20Green\% 20Interiors\%20Ratings\%20System\%20Sep\%202019.pdf, accessed 22 July 2021.

[28] USGBC, "LEED v4.1 BUILDING DESIGN AND CONSTRUCTION Getting started guide for beta participants”,https://www.usgbc.org/sites/default/files/202 1-03/LEED\%20v4.1\%20BD\%2BC\%20Guide\%200409201 9.pdf, 2019, accessed 15 April 2021.

[29] REHVA, "How to operate HVAC and other building service systems to prevent the spread of the coronavirus (SARS-CoV-2) disease (COVID-19) in workplaces", REHVA COVID-19 guidance document, Federation of European Heating, Ventilation and Air Conditioning Associations. 2020.

[30] UKGBC, “Climate Change: UKGBC’s vision for a sustainable built environment is one that mitigates and adapts to climate change”, https://www.ukgbc.org/health-a nd-wellbeing/, accessed 11 April 2021. 